\title{
Social-psychological determinants of maternal pertussis vaccination acceptance during pregnancy among women in the Netherlands
}

Citation for published version (APA):

Anraad, C., Lehmann, B. A., Visser, O., van Empelen, P., Paulussen, T. G. W., Ruiter, R. A. C., Kamp, L., van der Maas, N. A. T., Barug, D., Ruijs, W. L. M., de Melker, H. E., Mollema, L., \& van Keulen, H. M. (2020). Social-psychological determinants of maternal pertussis vaccination acceptance during pregnancy among women in the Netherlands. Vaccine, 38(40), 6254-6266.

https://doi.org/10.1016/j.vaccine.2020.07.047

Document status and date:

Published: 11/09/2020

DOI:

10.1016/j.vaccine.2020.07.047

Document Version:

Publisher's PDF, also known as Version of record

Document license:

Taverne

Please check the document version of this publication:

- A submitted manuscript is the version of the article upon submission and before peer-review. There can be important differences between the submitted version and the official published version of record.

People interested in the research are advised to contact the author for the final version of the publication, or visit the DOI to the publisher's website.

- The final author version and the galley proof are versions of the publication after peer review.

- The final published version features the final layout of the paper including the volume, issue and page numbers.

Link to publication

\footnotetext{
General rights rights.

- You may freely distribute the URL identifying the publication in the public portal. please follow below link for the End User Agreement:

www.umlib.nl/taverne-license

Take down policy

If you believe that this document breaches copyright please contact us at:

repository@maastrichtuniversity.nl

providing details and we will investigate your claim.
}

Copyright and moral rights for the publications made accessible in the public portal are retained by the authors and/or other copyright owners and it is a condition of accessing publications that users recognise and abide by the legal requirements associated with these

- Users may download and print one copy of any publication from the public portal for the purpose of private study or research.

- You may not further distribute the material or use it for any profit-making activity or commercial gain

If the publication is distributed under the terms of Article $25 \mathrm{fa}$ of the Dutch Copyright Act, indicated by the "Taverne" license above, 


\title{
Social-psychological determinants of maternal pertussis vaccination acceptance during pregnancy among women in the Netherlands
}

\author{
Charlotte Anraad ${ }^{\mathrm{a}, \mathrm{b}, *}$, Birthe A. Lehmann ${ }^{\mathrm{e}}$, Olga Visser ${ }^{\mathrm{d}}$, Pepijn van Empelen ${ }^{\mathrm{b}}$, Theo G.W. Paulussen ${ }^{\mathrm{b}}$, \\ Robert A.C. Ruiter ${ }^{\mathrm{a}}$, Laura Kamp ${ }^{\mathrm{c}}$, Nicoline A.T. van der Maas ${ }^{\mathrm{c}}$, Daantje Barug ${ }^{\mathrm{c}}$, Wilhelmina L.M. Ruijs ${ }^{\mathrm{c}}$, \\ Hester E. de Melker ${ }^{c}$, Liesbeth Mollema ${ }^{c}$, Hilde M. van Keulen ${ }^{\mathrm{b}}$ \\ ${ }^{a}$ Department of Work E Social Psychology, Faculty of Psychology and Neuroscience, Maastricht University, P.O. Box 616, 6200 MD Maastricht, the Netherlands \\ ${ }^{\mathrm{b}}$ TNO Child Health, Netherlands Organization for Applied Scientific Research, P.O. Box 3005, 2316 ZL Leiden, the Netherlands

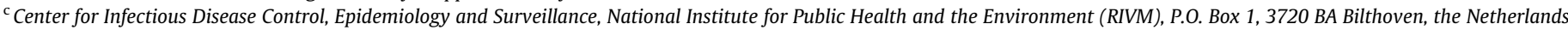 \\ ${ }^{\mathrm{d}}$ Radboud University Medical Centre (UMC), P.O. Box 9101, 6500 HB Nijmegen, the Netherlands \\ ${ }^{\mathrm{e}}$ Department of Persuasive Communication, Communication Science, University of Amsterdam, 1001 NH, Amsterdam
}

\section{A R T I C L E I N F O}

\section{Article history:}

Received 4 November 2019

Received in revised form 17 May 2020

Accepted 22 July 2020

Available online 8 August 2020

\section{Keywords:}

Vaccine hesitancy

Vaccine acceptance

Maternal pertussis vaccination

Vaccination during pregnancy

Informed choice

Social-psychological determinants

\begin{abstract}
A B S T R A C T
Background: Maternal Pertussis Vaccination (MPV) during pregnancy became part of the National Immunization Program in the Netherlands late 2019. This study aims to identify social-psychological factors associated with MPV acceptance among Dutch women to add to the current understanding of vaccine hesitancy worldwide, and to inform the development of communication and information campaigns about MPV.

Methods: We conducted a cross-sectional study using an online survey among 611 women (174 pregnant women, 205 women who had given birth in the past two years and 232 women of 20-35 years old). The primary and secondary outcomes were vaccination intention and attitude towards MPV, respectively. Pearson's correlation and regression analyses were used to examine social-psychological and sociodemographic determinants of the outcomes.

Results: Vaccination intention was most explained by attitudes towards MPV, beliefs about safety, moral norm and the belief about the effectiveness of MPV $\left(R^{2}=0.79\right)$. Other factors associated were injunctive norm, anticipated regret of vaccinating, and decisional certainty. Attitudes towards MPV were further explained by descriptive norm, risk perceptions of side effects, and risk perceptions of the baby getting pertussis when not vaccinating, and fear of MPV and of the disease $\left(R^{2}=0.76\right)$. Finally, pregnant women had a significantly lower intention and less positive attitude towards MPV than non-pregnant women. Conclusions: Communication about MPV should address the most important determinants of MPV intention and attitude, i.e. beliefs about safety and effectiveness and moral norms. Furthermore, such information may benefit from taking into account affective feelings of pregnant women such as anticipated regret and fear towards MPV. Further research could explore this. The timing of communication about MPV can be important as determinants of MPV acceptance may vary depending on pregnancy status.
\end{abstract}

(c) 2020 Elsevier Ltd. All rights reserved.

\section{Introduction}

Pertussis, commonly known as whooping cough, is an infection of the respiratory tract caused by the bacterium Bordetella Pertussis. Pertussis is most severe among infants younger than six months, who are too young to be (fully) protected by vaccination. About half of young infants who get pertussis require hospital care and

\footnotetext{
* Corresponding author at: Maastricht University, Department of Work \& Social Psychology, P.O. Box 616, 6200 MD Maastricht, the Netherlands.

E-mail address: charlotte.anraad@maastrichtuniversity.nl (C. Anraad).
}

in rare cases, pertussis in babies may lead to convulsion, encephalopathy and even death [1]. Pertussis incidence in the Netherlands has increased since 1996, with a rate of up to 63 per 100,000 during an outbreak in 2011-2012 [2]. From 2005 until $2014,1,711$ cases of pertussis were reported in Dutch infants. Of these cases 1,279 were five months of age or younger with 1,020 being admitted to hospital and five mortalities [3]. In December 2019 maternal immunization during pregnancy (i.e., 'maternal pertussis vaccination' or MPV) with the TdaP vaccine, containing Tetanus, Diphtheria an acellular Pertussis, was introduced in the 
National Immunization Program (NIP) in the Netherlands to protect infants from pertussis in their first months of life [3].

The Netherlands has seen a decline in vaccination uptake since 2003 , which stabilized at $90.2 \%$ of children completely enrolled in the program in 2018. There is however vaccine-specific hesitancy, with for example a lower uptake of HPV vaccination $(45,4 \%$ in 2018). DTaP vaccination for children had an uptake of $92.5 \%$ in 2018, with a lower uptake in religious areas [4]. Besides the vaccination against H1N1 influenza (2009) during an outbreak, there is no experience with vaccination of pregnant women in the Netherlands [5]. The uptake of H1N1 vaccination among pregnant women was $63 \%$. It appeared that mothers' beliefs about the protection of the child and possible harmful effects of the vaccine for the unborn child, and the government's, GP's and midwife's advice best predicted vaccination status [6].In the UK, where MPV was introduced in 2012 in response to increased pertussis incidence, uptake stabilized around 70\% in 2017 [7]. In the United States of America, coverage was 54.4\% in 2017 [8]. In Australia, coverage was estimated at $85.2 \%$ in 2017 [9].

To effectively communicate and facilitate an informed choice regarding MPV among pregnant women, it is important to gain further understanding of reasons that might hamper or promote MPV acceptance. Even more so because choices and experiences surrounding maternal vaccination appear to impact later decision making processes on childhood vaccination [10]. A literature review by Wilson et al. (2015) [11] found that factors associated with vaccine uptake during pregnancy were beliefs about the vaccine safety and effectiveness [12-15], a desire to protect the baby [16], perceived risk (i.e., perceived susceptibility of the baby to get pertussis if not vaccinated, and perceived severity of the disease) $[13,14]$, the opinion of the partner [17], the recommendation by a healthcare professional to get the vaccine $[12,13,15,16,18-21]$, and the logistic convenience to get the vaccine [16]. In the Netherlands, insights into the reasons for MPV acceptance are lacking. A study on the acceptance of a cocooning strategy among parents (where the parents get vaccinated to prevent infecting the child) found attitude, anticipated regret, and decisional certainty to be associated with vaccine acceptance [22]. It is unclear which factors are of influence at different moments in the decision making process, for example before or during pregnancy. Insights in these factors could guide the development of communication about MPV to facilitate informed decision making and decrease decisional conflict.

This study aims to identify social-psychological factors associated with MPV acceptance among Dutch women who are pregnant and who are not pregnant or have recently given birth. These determinants are theoretically based on social cognitive theories to explain human behavior, in particular the Health Belief Model (HBM) and the Theory of Planned Behavior (TPB) [23,24]. Besides, factors such as beliefs about safety and effectiveness, decisional certainty, moral norms, and risk perception are suggested to be critical by the existing literature on vaccine acceptance in pregnancy and by focus groups on vaccine acceptance in a cocooning strategy $[12-16,19,22,25]$. We included both pregnant and nonpregnant women to examine whether the findings for pregnant women are different compared to non-pregnant women, as different factors may be of influence during different moments of the decision making process.

\section{Methods}

\subsection{Study design}

This is a cross-sectional, survey based study.

\subsection{Participants}

A questionnaire was set out in April 2017 among two existing, online panels organized via Flycatcher, a private, ISO 26,362 certified research company. People could join the panel online and by participating in online questionnaires, the panel members could collect points that can be exchanged for gift vouchers. Panel members were recruited via e-mail if they represented women who (a) were pregnant and therefore in the position to decide about maternal vaccination, (b) had given birth within the last two years and could imagine how they would have felt making the decision, or (c) did not have children, but were of child bearing age (20-35). Participants were excluded if response rate was insufficient or if they explicitly indicated that they did not have a wish to become pregnant. They were also excluded if they had already received MPV during their current pregnancy, because this could cause confirmation bias, i.e. people are more likely to be positive about the vaccination if they have already received it.

\subsection{The online questionnaire}

The survey was based on two general theoretical frameworks, the Theory of Planned Behavior (TPB) and Health Belief Model (HBM). The Theory of Planned Behavior (TPB) argues that intention (i.e. the intention to perform a certain behavior) is the main predictor of behavior, which is in turn predicted by attitude and perceived social norms [24]. According to the Health Belief Model (HBM), a decision to engage in certain health behavior is determined by risk perception. Risk perception results from the extent to which one perceives oneself susceptible to a health threat ("perceived susceptibility') and the extent to which one perceives the threat as severe ('perceived severity'). In addition, the likelihood to perform the behavior depends on the perceived benefits of and barriers to that behavior [23,26].

Attitude is defined as "the degree to which a person has a favorable or unfavorable evaluation or appraisal of the behavior in question" [24]. Social influences are constituted by descriptive norms and injunctive norms. Descriptive norms refer to the expected behavior of other people, i.e. whether other pregnant women are expected to receive MPV.

Risk perceptions (i.e. perceived severity and susceptibility) of side effects for the mother and the child, and the baby getting whooping cough when not vaccinating were included in this study. This also accounts for outcome expectancies, referring to a person's estimation of the benefits and barriers of accepting MPV, beliefs about the vaccine's effectiveness and safety, as well as beliefs about alternative strategies for the prevention of whooping cough. Because some people may hold both positive and negative beliefs about the vaccination, the concepts of outcome expectancies and beliefs about the safety of the vaccine are based on weighing both beliefs in favor and in disfavor of the vaccine.

In the case of vaccine acceptance [27], research has shown that decisions are not only influenced by cognitive biases [28]. Since affective factors appear important too [29], we also included anticipated regret of vaccinating, fear of MPV or of the baby suffering from whooping cough, feelings of trust in the NIP, the government and the Dutch National Institute for Public Health and the Environment, i.e. the RIVM [27]. Previous experiences with other vaccinations and with whooping cough, and the feeling that it is the moral responsibility of a pregnant woman to get MPV, i.e. moral norm, have been found to influence vaccine acceptance and were included in our study [30].

Because decisional certainty, i.e. the extent to which someone found it easy to make the decision or had doubts, has shown to influence vaccination behavior [22], we included a subscale of the complete decisional conflict scale by O'Connor (1995). This 
subscale consists of three items: 'deciding on MPV is something I have to give a lot of thought' ( $1=$ completely disagree to $7=\mathrm{com}$ pletely agree), 'I find deciding on MPV ...' ( 1 = very easy to 7 = very hard) and 'about the MPV decision I feel ...' ( 1 = very certain to 7 = very uncertain) [31].

Socio-demographics included were age, having children, country of birth, working in the healthcare sector, highest completed education (low and intermediate level versus high level of education), and affiliation with religion, homeopathy, natural care and/ or anthroposophy.

Table 1 provides an overview of all constructs measured, the number of items used for each construct, an example of an item that was used, the scales used, and the internal validity of each construct. Items targeting attitude, descriptive and injunctive norm, outcome expectancies, beliefs about safety of the vaccine, anticipated regret, fear of MPV or of the baby suffering from whooping cough and trust were measured on 7-point Likert scales. Perceived effectiveness of strategies to prevent pertussis in infants was measured on a 10-point scale. Items with the same underlying theoretical construct were averaged into a composite score when internal consistency was sufficient (Cronbach's alpha $\alpha>0.60$ or Pearson correlation coefficient $r>0.50)$. We have included the complete questionnaire in the appendix.

After giving informed consent, participants had access to the online questionnaire via a personalized link. Women who did not respond were sent a reminder one week after the start of the study. The online questionnaire consisted of 54 questions (see Table 1 for exemplary items). Non-pregnant women were asked to imagine how they would answer the questions in the case that they were pregnant. The questionnaire started with a brief introduction about whooping cough and the planned introduction of MPV during pregnancy, aimed to protect newborns against whooping cough. The exact text can be found in the appendix.

\subsection{Data analysis}

Data was analyzed using IBM's SPSS version 25. First, we analyzed means and standard deviations and Pearson's $r$ between study variables. Factors that by univariate analysis appeared significantly $(\mathrm{p}<0.05)$ associated with intention were included in a stepwise linear regression analysis on that criterion (backward selection). Social-psychological variables were added in the first step. Socio-demographic variables were added in the second step to correct for demographic variation. We report both the start and end-model of the regression analysis. Because attitude towards MPV appeared to be the strongest predictor of intention, we then repeated the same regression strategy with attitude towards MPV as criterion variable.

Decisional certainty is somewhat complex to interpret in a linear analysis because the scale only refers to the certainty of the decision and not to the extent to which someone is positive or negative about MPV. It has a possible moderating effect on the relationship between vaccination intention and its determinants, because the extent to which determinants are of influence on health behavior may depend on the extent to which these determinants are certain [32]. Therefore, moderation of the associations between determinants of intention and intention by decisional certainty was explored by adding interaction terms to the linear regression models, with the interaction terms made with the centered values for decisional certainty and the variable associated with intention. If the $\mathrm{R}$ change was positive and the interaction term and $F$ change were significant ( $p<0.05$ ), moderation was further explored in a multivariate model with decisional certainty and the concerning dependent variables. The most persistent moderators were then looked at in more detail using simple slopes analyses [33]. We computed slopes for the regression of those attitudinal variables on intention at three levels of the moderator variable decisional certainty: one standard deviation above or below the mean (low and high) and the mean level (moderate). The simple slope analyses were done using PROCESS version 3.1 by Andrew Hayes (model 1), using centered variables and 5000 bootstrap samples.

Because we found that pregnancy status was significantly associated with the criterion in our regression models (i.e. vaccination intention), differences in mean scores on all variables were tested between pregnant and non-pregnant women by independent sample t-tests, using $95 \%$ confidence intervals.

\section{Results}

\subsection{Sample}

Fig. 1 shows the inclusion of participants. In total 736 women started with the survey and 664 women completed it. Women were excluded when response quality was insufficient $(n=19)$, when they had already received MPV during their current pregnancy $(n=28)$, or when they explicitly indicated that they did not want to become pregnant $(n=6)$. In total 611 women were included in the analyses, including pregnant women $(\mathrm{n}=174$, of which 68 did not yet have children), women who had given birth to a child within the two years preceding the questionnaire ( $n=205$ ), women aged 20-35 who were not pregnant and did not have children yet $(n=232)$. Participants were on average 30 years old. Women who were born in the Netherlands (96\%), were highly educated (76\%) and who worked in the healthcare sector $(38 \%)$ were overrepresented. Table 2 shows the mean scores on all social-psychosocial measures. Intention towards MPV was scored neutral $(\mathrm{M}=4.11 ; \mathrm{SD}=1.57)$ while attitude was more positive about vaccination in general than about MPV in particular. One should be cautious with interpreting differential mean scores on beliefs about vaccines people are already familiar with for years versus beliefs about a new vaccine to be implemented by the NIP.

\subsection{Correlations}

Table 3 shows the Pearson's $r$ between social-psychological variables and MPV intention. Cohen (1988) argues that correlations of $r=0.10$ to23 are indicative for a small effect size, $r=0.24$ to.36 for a moderate effect size, and $r \geq 0.37$ for a large effect size [34]. Table 3 shows that large associations with intention were found for attitude, beliefs about safety, moral norms and beliefs about the effectiveness of MPV. Large effects were also found for outcome expectancies, injunctive norms, trust, attitude about vaccines in general, and fear of the vaccine. Weaker correlations, but still indicating large effects were found for decisional certainty, risk perceptions of side effects, descriptive norms, and fear of the disease. Moderate effect sizes were found for anticipated regret, and small effect sizes for beliefs about the effectiveness of a healthy lifestyle as a strategy to protect against whooping cough.

\subsection{Regression analyses of intended MPV uptake}

Table 4 shows that the linear regression model explained $79 \%$ of the intention to accept MPV, both with and without a stepwise backwards selection of determinants. The Akaike Information Criterion (AIC) is lower for the model with backwards selection than for the model with all variables, indicating that the backwards model presents a better fit. In the model with backwards selection, attitude towards MPV appeared the strongest determinant of intention $(\beta=0.45)$, followed by moral norms $(\beta=0.20)$. Other determinants in the model were beliefs about safety, decisional 
Table 1

Psychosocial variables and their internal reliability.

\begin{tabular}{|c|c|c|c|}
\hline Variable & Nr of items & Reliability & Example question \\
\hline Intention & 3 & $\alpha=0.98$ & $\begin{array}{l}\text { I would be willing to get vaccinated against whooping cough during pregnancy. } 1=\text { completely disagree to } \\
7 \text { = completely agree }\end{array}$ \\
\hline \multicolumn{4}{|r|}{ ( } \\
\hline Attitude MPV & 5 & $\alpha=0.95$ & $\begin{array}{l}\text { I think vaccination against whooping cough during pregnancy is: } 1=\text { not important at all to } 7=\text { very } \\
\text { important }\end{array}$ \\
\hline \multicolumn{4}{|l|}{$1=$ negative $-7=$ positive } \\
\hline Attitude vaccines in general & 4 & $\alpha=0.92$ & In general, I think vaccination is: 1 = very unnecessary to 7 = very necessary \\
\hline \multicolumn{4}{|l|}{$1=$ negative $-7=$ positive } \\
\hline Outcome expectancies & 7 & $\alpha=0.87$ & $\begin{array}{l}\text { Vaccination against whooping cough during pregnancy leads to less pertussis among babies. } \\
1=\text { completely disagree to } 7=\text { completely agree }\end{array}$ \\
\hline \multicolumn{4}{|r|}{ 然 } \\
\hline Moral norm & 2 & $r=0.89$ & $\begin{array}{l}\text { I think that it is my responsibility as a pregnant woman to get vaccinated against whooping cough during } \\
\text { pregnancy to protect my baby. } 1=\text { completely disagree to } 7=\text { completely agree }\end{array}$ \\
\hline $\begin{array}{l}1=\text { low }-7=\text { high } \\
\text { Risk Perception of pertussis in } \\
\text { baby if not vaccinating }\end{array}$ & $\begin{array}{l}2 \\
\left(\text { multiplied }^{*}\right)\end{array}$ & NA & How severe is whooping cough according to you? $0=$ not severe to $6=$ very severe \\
\hline \multicolumn{4}{|l|}{$1=$ low -42 = high } \\
\hline $\begin{array}{l}\text { Risk Perception side effects } \\
\quad \text { vaccine }\end{array}$ & 2 & NA & $\begin{array}{l}\text { Imagine you get vaccinated against whooping cough during pregnancy, what do you think the chance is } \\
\text { that you will get side effects? } 0=\text { very small to } 6=\text { very big }\end{array}$ \\
\hline \multicolumn{4}{|l|}{$1=$ low $-42=$ high } \\
\hline $\begin{array}{l}\text { Risk Perception side effects } \\
\text { vaccine for the child }\end{array}$ & 2 & NA & $\begin{array}{l}\text { Imagine you get vaccinated against whooping cough during pregnancy, what do you think the chance is } \\
\text { that your baby gets side effects? } 1 \text { = very small to } 7 \text { = very big }\end{array}$ \\
\hline \multicolumn{4}{|l|}{$1=$ low -42 = high } \\
\hline Belief Safety & 7 & $\alpha=0.89$ & I think whooping cough vaccination during pregnancy is safe. \\
\hline $1=$ unsafe $-7=$ safe & & & $1=$ completely disagree to $7=$ completely agree \\
\hline Injunctive norm & 2 & $r=0.60$ & $\begin{array}{l}\text { The people who are important to me will appreciate if I get vaccinated against whooping cough during } \\
\text { pregnancy. } 1 \text { = completely disagree to } 7 \text { = completely agree }\end{array}$ \\
\hline \multicolumn{4}{|r|}{ 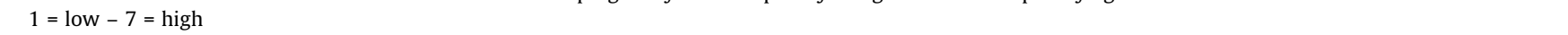 } \\
\hline Descriptive norm & 1 & NA & $\begin{array}{l}\text { Most pregnant women will get vaccinated against whooping cough during pregnancy. } 1=\text { completely } \\
\text { disagree to } 7 \text { = completely agree }\end{array}$ \\
\hline \multicolumn{4}{|r|}{ 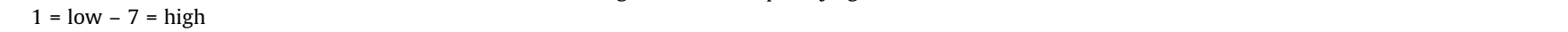 } \\
\hline $\begin{array}{l}\text { Anticipated regret of vaccinating } \\
\qquad 1=\text { low }-7=\text { high }\end{array}$ & 1 & NA & $\begin{array}{l}\text { Imagine you get vaccinated against whooping cough during pregnancy and your baby gets side effects, } \\
\text { how much regret would you feel about your decision to get vaccinated? } 1=\text { no regret at all to } 7=\text { a lot of } \\
\text { regret }\end{array}$ \\
\hline Decisional certainty & 3 & $\alpha=0.89$ & $\begin{array}{l}\text { Deciding whether to get vaccinated against whooping cough during my pregnancy is: } 1=\text { very difficult to } \\
7 \text { = very easy }\end{array}$ \\
\hline $\begin{array}{l}1=\text { uncertain }-7=\text { certain } \\
\text { Trust in NIP and healthcare } \\
\text { professionals }\end{array}$ & 3 & $\alpha=0.88$ & $\begin{array}{l}\text { How much trust do you have in information you get about pertussis vaccination during pregnancy from } \\
\text { your midwife (or other caregiver)/ the RIVM/ the government? } 1=\text { No trust at all to } 7=\text { A lot of trust }\end{array}$ \\
\hline \multicolumn{4}{|l|}{$1=$ low $-7=$ high } \\
\hline Past experience pertussis & 1 & NA & I have experienced that someone in my environment had whooping cough. No/Yes \\
\hline \multicolumn{4}{|l|}{$1=$ no $-2=$ yes } \\
\hline $\begin{array}{l}\text { Past experience pertussis in a } \\
\text { baby }\end{array}$ & 1 & NA & I have experienced that a baby in my environment had whooping cough. No/Yes \\
\hline \multicolumn{4}{|l|}{$1=$ no $-2=$ yes } \\
\hline $\begin{array}{l}\text { Past experience vaccine side } \\
\text { effects baby }\end{array}$ & 1 & NA & I have experienced that a baby in my environment had side effects from a vaccine. No/Yes \\
\hline \multicolumn{4}{|l|}{$1=$ no $-2=$ yes } \\
\hline Fear vaccination & 1 & NA & $\begin{array}{l}\text { When I think about getting vaccinated during pregnancy I feel fear. } 1 \text { = completely disagree to } \\
7 \text { = completely agree }\end{array}$ \\
\hline \multicolumn{4}{|l|}{$1=$ low $-7=$ high } \\
\hline Fear disease & 1 & NA & $\begin{array}{l}\text { When I think about my baby getting whooping cough I feel fear. } 1=\text { completely disagree to } 7=\text { completely } \\
\text { agree }\end{array}$ \\
\hline \multicolumn{4}{|r|}{ 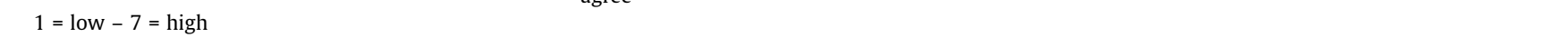 } \\
\hline Belief effectiveness MPV & 1 & NA & $\begin{array}{l}\text { Is, according to you, whooping cough vaccination during pregnancy an effective way to protect your baby } \\
\text { against whooping cough? } 1 \text { = not effective at all to } 10=\text { very effective }\end{array}$ \\
\hline $\begin{array}{l}1=\text { low }-10=\text { high } \\
\text { Belief effectiveness having } \\
\text { Pertussis }\end{array}$ & 1 & NA & $\begin{array}{l}\text { Is, according to you, the baby going through having whooping cough an effective way to protect your baby } \\
\text { against whooping cough? } 1 \text { = not effective at all to } 10=\text { very effective }\end{array}$ \\
\hline $\begin{array}{l}\quad 1=\text { low }-10=\text { high } \\
\text { Belief effectiveness breastfeeding }\end{array}$ & 1 & NA & $\begin{array}{l}\text { Is, according to you, breastfeeding an effective way to protect your baby against whooping cough? } 1=\text { not } \\
\text { effective at all to } 10=\text { very effective }\end{array}$ \\
\hline
\end{tabular}


Table 1 (continued)

\begin{tabular}{|c|c|c|c|}
\hline Variable & $\mathrm{Nr}$ of items & Reliability & Example question \\
\hline $\begin{array}{l}1=\text { low }-10=\text { high } \\
\text { Belief effectiveness healthy } \\
\text { lifestyle }\end{array}$ & 1 & NA & $\begin{array}{l}\text { Is, according to you, living in a healthy manner an effective way to protect your baby against whooping } \\
\text { cough? } 1 \text { = not effective at all to } 10 \text { = very effective }\end{array}$ \\
\hline
\end{tabular}

Note. NA = not applicable, $r=$ Pearson $r, \alpha=$ Cronbach's alpha.

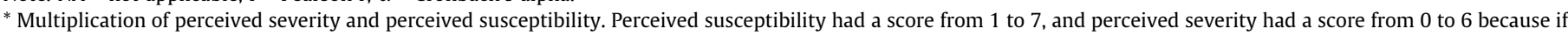

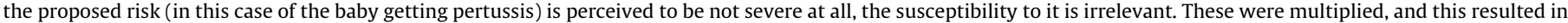
a scale varying from 0 to 42 in which 0 is a low risk perception and 42 is high risk perception.
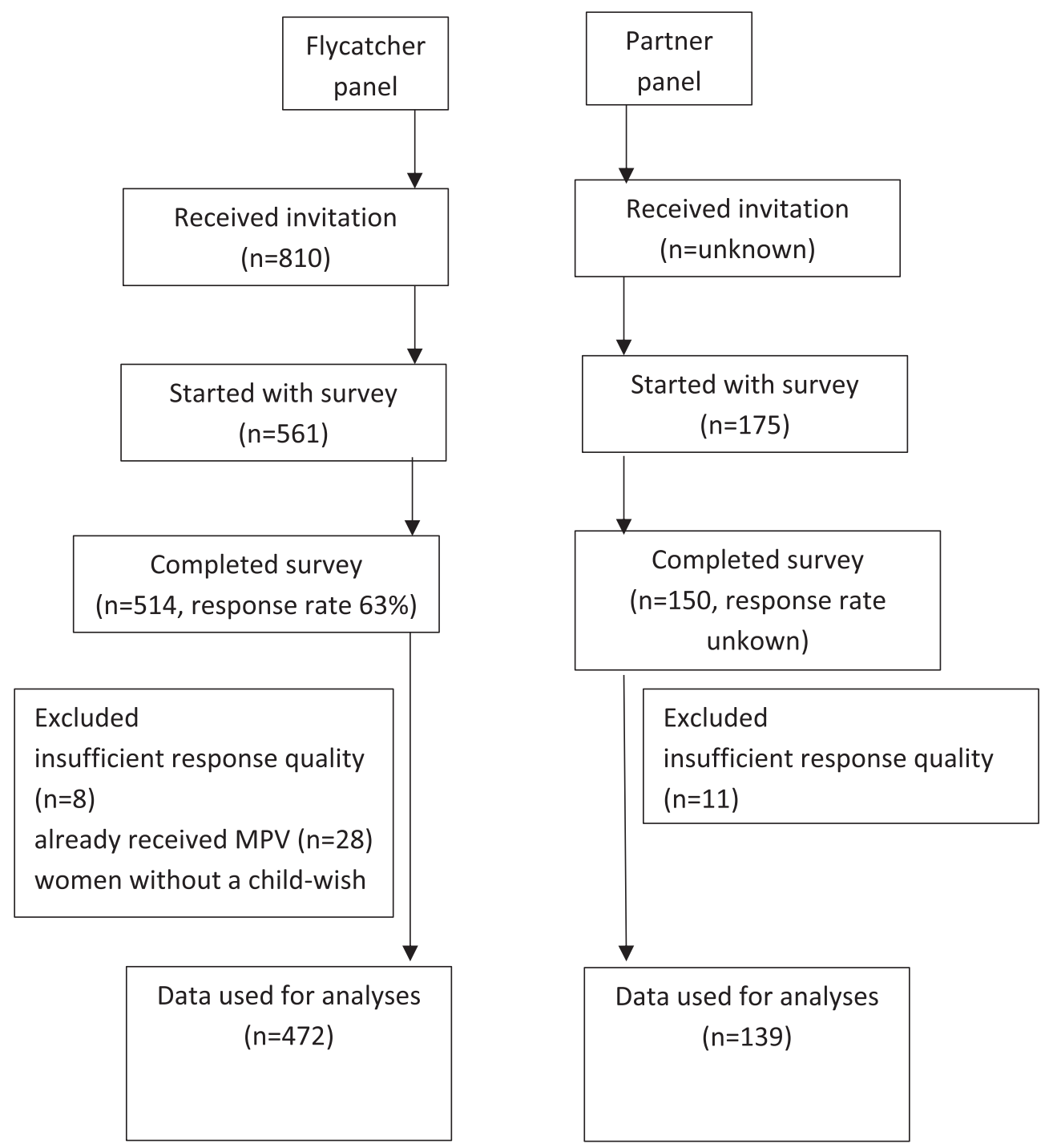

Fig. 1. Flow diagram of the recruitment and response of study participants.

certainty, injunctive norms, anticipated regret of vaccinating, beliefs about the effectiveness of MPV and breastfeeding as an alternative prevention strategy (all $\beta$ 's $>0.60$; all p-values $<0.05$ ).

The explained variance was $76 \%$ in the linear regression models predicting attitude towards MPV, and the AIC was lower for the backwards model, indicating a better fit model. Strongest associated with attitude towards MPV were beliefs about safety $(\beta=0.39)$ and the effectiveness of MPV $(\beta=0.27)$. Moral norms were also significantly associated with attitude towards MPV. Compared to model one, model two had lower significant betas for attitude about vaccines in general, risk perception of the child getting pertussis when not vaccinating, risk perception of the side effects for the child, descriptive norm, trust and fear of the vaccination and the disease(all $\beta$ 's $\geq 0.06$ all p-values $<0.05$ ).

Among the socio-demographics, being pregnant had a significant effect in both models, with a negative effect in model one 
Table 2

Sample description.

\begin{tabular}{|c|c|}
\hline Sociodemographic variables & $\begin{array}{l}\text { Mean (standard } \\
\text { deviation) } \\
\text { for continuous } \\
\text { variables and } \\
\text { percentages } \\
\text { for dichotomous } \\
\text { or categorical variables } \\
(\mathrm{n}=611)\end{array}$ \\
\hline $\begin{array}{l}\text { Age } \\
\text { Has at least one child }\end{array}$ & $30.34(4.64)$ \\
\hline $\begin{array}{l}\text { No } \\
\text { Yes }\end{array}$ & $\begin{array}{l}49.10 \% \\
50.90 \%\end{array}$ \\
\hline $\begin{array}{l}\text { Pregnant } \\
\text { No } \\
\text { Yes }\end{array}$ & $\begin{array}{l}71.52 \% \\
28.48 \%\end{array}$ \\
\hline $\begin{array}{l}\text { Country of birth } \\
\text { Netherlands } \\
\text { Other } \\
\text { Highest education completed }\end{array}$ & $\begin{array}{l}96.07 \% \\
3.93 \%\end{array}$ \\
\hline $\begin{array}{l}\text { Low or Intermediate } \\
\text { High }\end{array}$ & $\begin{array}{l}24.22 \% \\
75.78 \%\end{array}$ \\
\hline $\begin{array}{l}\text { Work in healthcare sector } \\
\qquad \text { No } \\
\text { Yes } \\
\text { Religion }\end{array}$ & $\begin{array}{l}62.03 \% \\
37.97 \% \\
2.48(2.01)\end{array}$ \\
\hline $\begin{array}{l}\quad 1=\text { no affiliation }-7=\text { strong affiliation } \\
\text { Homeopathy }\end{array}$ & $2.79(1.65)$ \\
\hline $\begin{array}{l}\quad 1=\text { no affiliation }-7=\text { strong affiliation } \\
\text { Natural Cure }\end{array}$ & $2.73(1.65)$ \\
\hline $\begin{array}{l}1=\text { no affiliation }-7=\text { strong affiliation } \\
\text { Anthroposophy }\end{array}$ & $2.15(1.47)$ \\
\hline $\begin{array}{l}\quad 1=\text { no affiliation }-7=\text { strong affiliation } \\
\text { Social-psychological variables } \\
\text { Intention }\end{array}$ & $4.11(1.57)$ \\
\hline $\begin{array}{l}\qquad 1=\text { low }-7=\text { high } \\
\text { Attitude MPV }\end{array}$ & $4.45(1.18)$ \\
\hline $\begin{array}{l}1 \text { = negative }-7 \text { = positive } \\
\text { Attitude vaccines in general }\end{array}$ & $5.78(1.21)$ \\
\hline $\begin{array}{l}1=\text { negative }-7=\text { positive } \\
\text { Outcome expectancies }\end{array}$ & $5.32(1.02)$ \\
\hline $\begin{array}{l}1=\text { negative }-7=\text { positive } \\
\text { Moral norm }\end{array}$ & $4.33(1.63)$ \\
\hline $\begin{array}{l}11=\text { low }-7=\text { high } \\
\text { Risk perception of pertussis in baby if not } \\
\text { vaccinating }\end{array}$ & $9.83(6.49)$ \\
\hline $\begin{array}{l}\quad 1 \text { = low }-49=\text { high } \\
\text { Risk perception side effects vaccine }\end{array}$ & $5.94(6.05)$ \\
\hline $\begin{array}{l}\quad 1=\text { low }-49=\text { high } \\
\text { Risk perception side effects vaccine for the child }\end{array}$ & $5.76(6.54)$ \\
\hline $\begin{array}{l}\quad 1=\text { low }-49=\text { high } \\
\text { Belief safety }\end{array}$ & $4.34(1.20)$ \\
\hline $\begin{array}{l}\quad 1=\text { unsafe }-7=\text { safe } \\
\text { Injunctive norm }\end{array}$ & $4.55(1.20)$ \\
\hline $\begin{array}{l}1=\text { low }-7=\text { high } \\
\text { Descriptive norm }\end{array}$ & $4.17(1.23)$ \\
\hline
\end{tabular}

Table 2 (continued)

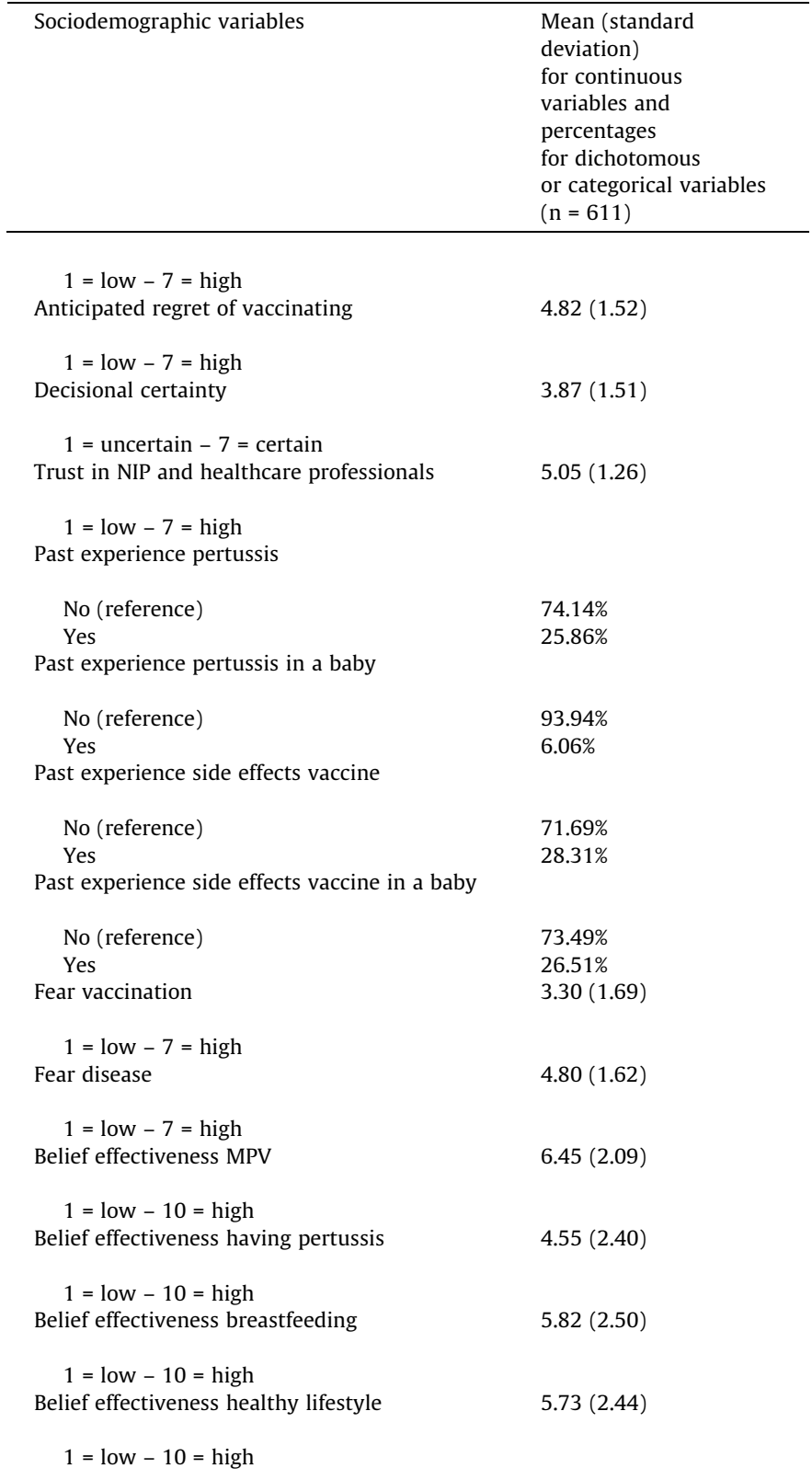

Note. * A higher score represents a stronger presence of the measured construct.

and a small but positive effect in model two $(\beta=-0.11 ; \mathrm{p}<.001$ versus $\beta=0.05 ; p<.05$, respectively). This means that pregnant women had a significantly lower vaccination intention and a significantly higher attitude towards MPV. Affiliation with natural cure and anthroposophy had a small but significant association with attitude towards MPV ( $\beta=-0.08$ and $\beta=0.06$, respectively; $\mathrm{p}<.05)$.

\subsection{Moderation by decisional certainty}

Small moderation effects of decisional certainty on the relation between each variable and intention were found for all socialpsychological variables (Table 7, appendix) in the univariate analyses and were most persistent for attitude towards MPV, outcome expectancies, and moral norms in the multivariate analyses. Because it may provide a direction for future research, we pre- 


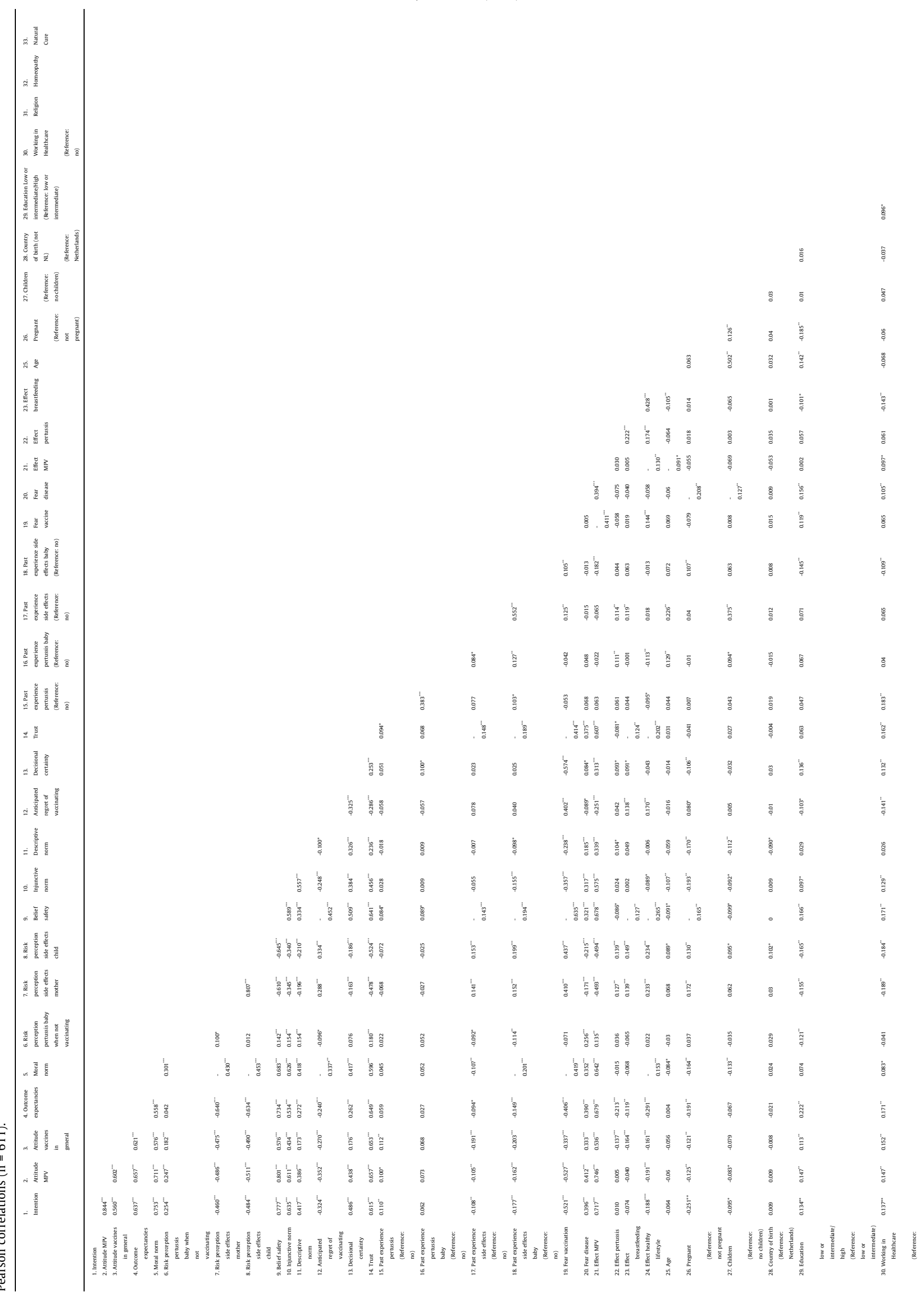


sented the simple slopes of the three moderated variables that were most strongly moderated in multivariate analyses in Table 5. This table shows that attitude towards MPV had a lower effect on intention under low decisional certainty $(B=0.94)$ than under moderate decisional certainty $(B=1.00)$ and under high decisional certainty $(B=1.05)$. This means that the effect of attitude towards MPV on vaccination intention is larger when participants are more certain about their decision. For attitude towards MPV there is no significant difference in unstandardized beta for the different levels of certainty, but for outcome expectancies and moral norm, there is.

3.5. Average differences between pregnant women and non-pregnant women.

Looking at pregnancy status, the intention to vaccinate was significantly lower among pregnant women than among nonpregnant women (mean difference $=0.87$ ). Table 6 shows that pregnant women scored lower on most determinants of intention. Their risk perceptions of side-effects of the vaccine for mother and child were significantly higher (mean differences $=-2.30$ and -1.87 respectively).

\section{Discussion}

\subsection{Main findings}

This study explored the determinants of intention to accept MPV during pregnancy among a sample of pregnant and nonpregnant women. Univariate analyses showed that attitude towards MPV had the strongest correlation with intention, followed by moral norms with regard to MPV, outcome expectancies, beliefs about safety and the effectiveness of MPV, injunctive norms, and trust in the NIP and the RIVM.

The multivariate analyses showed that the regression models were adequate in explaining intention (79\% of the variance) and attitude (76\%) towards MPV. Intention towards MPV was explained by attitude about MPV, moral norm, beliefs about safety, decisional certainty, injunctive norm, anticipated regret of vaccinating, and beliefs about the effectiveness of MPV. Attitude towards MPV was explained by beliefs about safety and the effectiveness of MPV, moral norm, attitude about vaccines in general, risk perception of the child getting pertussis when not vaccinating, risk perception of the side effects of MPV for the child, descriptive norm, fear of the vaccination and the disease and being pregnant. Pregnant women had a significantly lower intentions than nonpregnant women.

These findings align with earlier findings from other countries, suggesting that social-psychological factors associated with vaccine acceptance include beliefs about safety and effectiveness, as well as risk perception of the disease [12-15]. The association between injunctive norms and vaccination intention corresponds to earlier findings that the opinion of the partner of the respondent and recommendation by a healthcare professional influence acceptance of vaccines during pregnancy [12,13,15-21]. Moral norms towards MPV have been found to be of influence in a qualitative study on pertussis vaccine acceptance in a cocooning strategy [35]. Aside from attitude towards MPV and beliefs about the effectiveness of MPV, moral norm was the most robust determinant of vaccination intention, both in the univariate analyses and the multivariate regression analyses. According to norm-activation theory [36], moral norms will influence behavior when individuals are aware of the consequences of their actions for others and when they accept personal responsibility for those actions [37]. In the case of MPV, the choice to accept or refuse MPV may have conse- 
Table 4

Regression analyses of MPV intention (model 1) and attitude about MPV (model 2). $\mathrm{N}=611$.

\begin{tabular}{|c|c|c|c|c|c|c|c|c|}
\hline & \multicolumn{2}{|c|}{$\begin{array}{l}\text { Model 1a. Multivariate } \\
\text { regression with intention }\end{array}$} & \multicolumn{2}{|c|}{$\begin{array}{l}\text { Model } 1 \mathrm{~b} \text {. Multivariate } \\
\text { regression with backwards } \\
\text { selection with intention }\end{array}$} & \multicolumn{2}{|c|}{$\begin{array}{l}\text { Model 2a. Multivariate } \\
\text { regression with attitude about } \\
\text { MPV }\end{array}$} & \multicolumn{2}{|c|}{$\begin{array}{l}\text { Model } 2 \mathrm{~b} \text {. Multivariate } \\
\text { regression with backwards } \\
\text { selection } \\
\text { with attitude about MPV }\end{array}$} \\
\hline R2 (adjusted R2) & $0.80(0.79)$ & & $0.80(0.79)$ & & $0.77(0.76)$ & & $0.77(0.76)$ & \\
\hline $\mathrm{F}$ & $78.50^{* * *}$ & & $145.13^{* * *}$ & & $67.42^{* * *}$ & & $98.16^{* * *}$ & \\
\hline AIC & -378.33 & & -387.81 & & -637.34 & & -650.02 & \\
\hline Social psychological variables & $\begin{array}{l}\text { Unstandardized } \\
\text { beta (standard } \\
\text { error) }\end{array}$ & $\begin{array}{l}\text { Standardized } \\
\text { beta }\end{array}$ & $\begin{array}{l}\text { Unstandardized } \\
\text { beta (standard } \\
\text { error) }\end{array}$ & $\begin{array}{l}\text { Standardized } \\
\text { beta }\end{array}$ & $\begin{array}{l}\text { Unstandardized } \\
\text { beta (standard } \\
\text { error) }\end{array}$ & $\begin{array}{l}\text { Standardized } \\
\text { beta }\end{array}$ & $\begin{array}{l}\text { Unstandardized } \\
\text { beta (standard } \\
\text { error) }\end{array}$ & $\begin{array}{l}\text { Standardized } \\
\text { beta }\end{array}$ \\
\hline Attitude MPV & $0.56(0.05)$ & $0.42^{* * *}$ & $0.60(0.05)$ & $0.45^{* * *}$ & $\mathrm{NA}$ & NA & NA & NA \\
\hline Attitude vaccines in general & $-0.01(0.04)$ & -0.01 & - & - & $0.08(0.03)$ & $0.09^{* *}$ & $0.08(0.03)$ & $0.08^{* * *}$ \\
\hline Outcome expectancies & $0.02(0.06)$ & 0.01 & - & - & $-0.03(0.05)$ & -0.02 & - & - \\
\hline Moral norm & $0.19(0.03)$ & $0.19^{* * *}$ & $0.20(0.03)$ & $0.20^{* * *}$ & $0.07(0.02)$ & $0.10^{* *}$ & $0.08(0.02)$ & $0.11^{* * *}$ \\
\hline $\begin{array}{l}\text { Risk perception pertussis child } \\
\text { when not vaccinating }\end{array}$ & $0.01(<0.01)$ & 0.03 & - & - & $0.01(<0.01)$ & $0.06^{* *}$ & $0.01(<0.01)$ & $0.06^{* *}$ \\
\hline Risk perception side effects & $0.01(<0.01)$ & 0.02 & - & - & $0.01(<0.01)$ & $<0.01$ & - & - \\
\hline $\begin{array}{l}\text { vaccine mother } \\
\text { Risk perception side effects }\end{array}$ & $<0.01(0.01)$ & 0.01 & - & - & $0.01(0.01)$ & 0.05 & $0.01(<0.01)$ & $0.06^{*}$ \\
\hline vaccine child & & & & & & & & \\
\hline Belief safety & $0.19(0.06)$ & $0.18^{* *}$ & $0.18(0.05)$ & $0.14^{* * *}$ & $0.37(0.04)$ & $0.38^{* * *}$ & $0.38(0.04)$ & $0.39^{* * *}$ \\
\hline Injunctive norm & $0.06(0.04)$ & 0.05 & $0.08(0.03)$ & $0.06^{*}$ & $0.04(0.03)$ & 0.04 & - & - \\
\hline Descriptive norm & $0.02(0.03)$ & 0.02 & - & - & $0.04(0.02)$ & 0.04 & $0.06(0.02)$ & $0.06^{* *}$ \\
\hline $\begin{array}{l}\text { Anticipated regret of } \\
\text { vaccinating }\end{array}$ & $0.04(0.02)$ & 0.04 & - & - & $<0.01(0.02)$ & 0.01 & - & - \\
\hline Decisional certainty & $0.08(0.03)$ & $0.08^{* *}$ & $0.08(0.02)$ & $0.08^{* * *}$ & $0.02(0.02)$ & 0.03 & - & - \\
\hline Trust & $<0.01(0.04)$ & $<0.01$ & - & - & $0.07(0.03)$ & $0.07^{*}$ & $0.06(0.03)$ & $0.07^{*}$ \\
\hline Past experience pertussis & & & - & - & & & - & - \\
\hline No (reference) & & & & & & & & \\
\hline Yes & $0.11(0.07)$ & 0.03 & & & $0.05(0.06)$ & 0.02 & & \\
\hline $\begin{array}{l}\text { Past experience side effects } \\
\text { vaccine }\end{array}$ & & & - & - & & & - & - \\
\hline $\begin{array}{l}\text { No (reference) } \\
\text { Yes }\end{array}$ & $-0.04(0.08)$ & -0.01 & & & $<0.01(0.07)$ & $<0.01$ & & \\
\hline $\begin{array}{l}\text { Past experience side effects } \\
\text { vaccine in a baby }\end{array}$ & & & - & - & & & - & - \\
\hline No (reference) & & & & & & & & \\
\hline Yes & $-0.05(0.09)$ & -0.02 & & & $0.06(0.07)$ & 0.02 & & \\
\hline Fear vaccination & $-0.03(0.03)$ & -0.03 & - & - & $-0.04(0.02)$ & $-0.06^{*}$ & $-0.05(0.02)$ & $-0.07^{* *}$ \\
\hline Fear pertussis & $0.04(0.02)$ & 0.04 & - & - & $0.05(0.02)$ & $0.07^{* *}$ & $0.05(0.02)$ & $0.07^{* *}$ \\
\hline $\begin{array}{l}\text { Effectiveness MPV against } \\
\text { pertussis }\end{array}$ & $0.06(0.02)$ & $0.08^{*}$ & $0.06(0.02)$ & $0.08^{* *}$ & $0.15(0.02)$ & $0.27^{* * *}$ & $0.15(0.02)$ & $0.27^{* * *}$ \\
\hline $\begin{array}{l}\text { Effectiveness healthy lifestyle } \\
\text { Sociodemographic variables }\end{array}$ & $<0.01(0.01)$ & -0.02 & - & - & $<0.01(0.01)$ & -0.01 & - & - \\
\hline $\begin{array}{l}\text { Age } \\
\text { Pregnant }\end{array}$ & $<0.01(0.01)$ & $<0.01$ & $<0.01(<0.01)$ & $<0.01$ & $<0.01(0.01)$ & $<0.01$ & $<-0.01(0.01)$ & $<-0.01$ \\
\hline No (reference) & $-0.38(0.07)$ & $-0.11^{* * *}$ & & & $0.13(0.06)$ & $0.05^{*}$ & & \\
\hline Yes & & & $-0.37(0.07)$ & $-0.11^{* * *}$ & & & $0.13(0.05)$ & $0.05^{*}$ \\
\hline Has at least one child & & & & & & & & \\
\hline No (reference) & $0.03(0.07)$ & 0.01 & & & $<0.01(0.06)$ & $<0.01$ & & \\
\hline Yes & & & $0.01(0.07)$ & $<0.01$ & & & $0.03(0.06)$ & 0.01 \\
\hline Country of birth & & & & & & & & \\
\hline Netherlands (reference) & & & & & & & & \\
\hline Other & $0.02(0.15)$ & $<0.01$ & & & $<0.01(0.12)$ & $<0.01$ & & \\
\hline Highest education completed & & & $0.02(0.15)$ & $<0.01$ & & & $0.01(0.12)$ & $<0.01$ \\
\hline $\begin{array}{l}\text { Low or intermediate } \\
\text { (reference) }\end{array}$ & & & & & & & & \\
\hline High & $-0.04(0.07)$ & -0.01 & $-0.05(0.07)$ & -0.01 & $0.04(0.06)$ & 0.02 & $0.05(0.06)$ & 0.02 \\
\hline Work in healthcare sector & & & & & & & & \\
\hline No (reference) & & & & & & & & \\
\hline Yes & $0.02(0.06)$ & 0.01 & & & $0.03(0.05)$ & 0.01 & & \\
\hline & & & $0.01(0.06)$ & $<0.01$ & & & $0.04(0.05)$ & 0.02 \\
\hline
\end{tabular}


Table 4 (continued)

\begin{tabular}{|c|c|c|c|c|c|c|c|c|}
\hline \multirow[b]{2}{*}{ Religion } & \multicolumn{2}{|c|}{$\begin{array}{l}\text { Model 1a. Multivariate } \\
\text { regression with intention }\end{array}$} & \multicolumn{2}{|c|}{$\begin{array}{l}\text { Model 1b. Multivariate } \\
\text { regression with backwards } \\
\text { selection with intention }\end{array}$} & \multicolumn{2}{|c|}{$\begin{array}{l}\text { Model 2a. Multivariate } \\
\text { regression with attitude about } \\
\text { MPV }\end{array}$} & \multicolumn{2}{|c|}{$\begin{array}{l}\text { Model } 2 \text { b. Multivariate } \\
\text { regression with backwards } \\
\text { selection } \\
\text { with attitude about MPV }\end{array}$} \\
\hline & $-0.01(0.02)$ & -0.02 & $-0.01(0.02)$ & -0.01 & $0.01(0.01)$ & 0.02 & $0.01(0.01)$ & 0.02 \\
\hline Homeopathy & $0.03(0.03)$ & 0.03 & $0.03(0.03)$ & 0.04 & $0.01(0.03)$ & 0.01 & $0.01(0.03)$ & 0.01 \\
\hline Natural cure & $<0.01(0.03)$ & $<-0.01$ & $-0.01(0.03)$ & -0.01 & $-0.06(0.03)$ & $-0.08^{*}$ & $-0.06(0.03)$ & $-0.08^{*}$ \\
\hline Anthroposophy & $-0.02(0.03)$ & -0.02 & $-0.02(0.03)$ & -0.02 & $0.05(0.02)$ & $0.06^{*}$ & $0.05(0.02)$ & $0.06^{*}$ \\
\hline
\end{tabular}

Note. ${ }^{*} \mathrm{p}<.05 .{ }^{* *} \mathrm{p}<.01 .{ }^{* * *} \mathrm{p}<.001$.

Table 5

Simple slope analysis. Values are unstandardized regression coefficients for intention $(n=611)$ with 95\% confidence intervals at different levels of decisional certainty.

\begin{tabular}{llll}
\hline Variable & \multicolumn{2}{l}{ Level of decisional certainty } \\
\cline { 2 - 4 } & Low & Moderate & High \\
\hline Attitude MPV & $0.94(0.83-1.04)$ & $1.00(0.93-1.07)$ & $1.05(0.99-1.11)$ \\
Outcome expectancies & $0.49(0.35-0.63)$ & $0.76(0.67-0.85)$ & $0.98(0.89-1.08)$ \\
Moral norm & $0.45(0.38-0.52)$ & $0.61(0.56-0.67)$ & $0.75(0.69-0.80)$ \\
\hline
\end{tabular}

quences for the child once it is born, and might be activated when women become aware of the risks of accepting or refusing the vaccine. Contrarily, non-pregnant women appeared to feel more of a moral obligation to vaccinate than pregnant women. This may be due to a lower risk perception of side-effects of the vaccine in non-pregnant women than in pregnant women.

We found moderating effects of decisional certainty for almost all variables in the univariate analyses, with stronger effects on intention under high certainty than under low certainty, although these effects did not persist in multivariate regression models. However, low decisional certainty can be a sign of attitudinal ambivalence (holding both positive and negative beliefs on a subject simultaneously) and this has been found to moderate the attitude-behavior relationship in research studying other health behaviors [38]. Measurements of intention, attitude and decisional certainty may have some level of interdependence, and independent measurements are needed to firmly state that effects of attitude are lower under a low decisional certainty than under high decisional certainty. Therefore, it would have been ideal to include behavior instead of intention in the moderation analysis. Attitudinal ambivalence can lead to negative affect surrounding decision making [39] and individuals with high attitudinal ambivalence towards specific behavior are more pliable and less stable over time in performing these behaviors [40].

Intention and associated variables were lower among pregnant women than among non-pregnant women. The regression analyses and mean differences show a larger difference in intention than attitude towards MPV between pregnant and non-pregnant women. A possible explanation for these differences is the socalled hot-cold empathy gap. 'Cold' being the group of nonpregnant women, who do not have to make the decision yet, 'hot' being the group of pregnant women who are closer in time to the decision on MPV. Cold-to-hot empathy gaps in medical decision making were first described by Loewenstein (2005) as: “.... people mis-predict their own behavior and preferences across affective states. When people are in an affectively 'cold' state, they fail to fully appreciate how 'hot' states will influence their own preferences and behavior" [41]. In this context, vaccination intention and its determinants are lower among pregnant women, for whom the choice is more urgent compared to non-pregnant women.

\subsection{Limitations}

This study has limitations. First, the size of the group pregnant women ( $n=174)$ within the sample is small to make robust statements about the extent to which different factors are key in the decision making process, but this study does provide an exploratory view on the differences in factors related to the intention to accept MPV between pregnant and non-pregnant women. A second limitation is the generalizability of the sample from the panel, of which most women were highly educated and born in the Netherlands, and a relatively high percentage working in healthcare. We left sociodemographic factors in the regression models to correct these factors. Third, this is a cross-sectional study, whereas a longitudinal study would be ideal to be able to measure the influence of the factors over time and to infer causality and also to include MPV uptake instead of vaccination intention. Finally, it would be ideal to measure vaccination uptake as well as vaccination intention but this was not possible at the time of the study because MPV was not yet implemented in the NIP.

\subsection{Implications for future research}

First, because in our study, cognitive social-psychological variables associated with vaccination intention score lower among pregnant women than among non-pregnant women, affectrelated factors could be at play. Further research could aim to understand in what way affect-related determinants influence maternal vaccination acceptance during pregnancy. Second, future studies identifying determinants of vaccine uptake could also include possible moderation on the attitude-intention relationship by decisional certainty, because we found that this may be occurring. Third, in this study we measured the moral norm of accepting the vaccine, whereas some women may find it their moral responsibility to refuse the vaccine.

Because we found striking differences between non-pregnant women and pregnant women in socio-psychological determinants, longitudinal studies are needed to explain the decision making process of pregnant women from preconception to postnatal. Additionally, different communication strategies can be tested based on the determinants found, including strategies that have more attention to affect and emotions, rather than fact-based information.

\subsection{Implications for practice}

First, our study found that attitude towards MPV is key for vaccination intention and that both are significantly associated with moral norms, beliefs about the effectiveness and safety of MPV, outcome expectancies, injunctive norm, trust in the NIP, decisional certainty and risk perceptions. To promote informed choice and to meet the information need of pregnant women, these key factors should be addressed in future communication about MPV. It is important to note that the two components of risk perception, 
Table 6

Mean differences between pregnant women $(n=174)$ and non-pregnant women $(n=437)$.

\begin{tabular}{|c|c|c|c|c|c|}
\hline & \multirow[t]{2}{*}{$\begin{array}{l}\text { Mean (standard deviation) } \\
\text { pregnant women }\end{array}$} & \multirow[t]{2}{*}{$\begin{array}{l}\text { Mean (standard deviation.) } \\
\text { non-pregnant women }\end{array}$} & \multirow[t]{2}{*}{ Mean difference Variable } & \multicolumn{2}{|c|}{$\begin{array}{l}95 \% \text { interval of } \\
\text { the difference }\end{array}$} \\
\hline & & & & Lower & Upper \\
\hline Intention & $3.49(1.47)$ & $4.36(1.54)$ & $0.87^{*}$ & 0.60 & 1.14 \\
\hline $\begin{array}{l}1=\text { low }-7=\text { high } \\
\text { Attitude MPV }\end{array}$ & $4.22(1.08)$ & $4.54(1.21)$ & $0.33^{*}$ & 0.13 & 0.52 \\
\hline $\begin{array}{l}1=\text { negative }-7=\text { positive } \\
\text { Attitude vaccines in general }\end{array}$ & $5.54(1.26)$ & $5.87(1.18)$ & $0.33^{*}$ & 0.11 & 0.54 \\
\hline $\begin{array}{l}1=\text { negative }-7=\text { positive } \\
\text { Outcome Expectancies }\end{array}$ & $5.01(0.96)$ & $5.44(1.01)$ & $0.43^{*}$ & 0.25 & 0.61 \\
\hline $\begin{array}{l}1=\text { negative }-7=\text { positive } \\
\text { Moral norm }\end{array}$ & $3.91(1.53)$ & $4.50(1.63)$ & $0.59^{*}$ & 0.31 & 0.87 \\
\hline $\begin{array}{l}\quad 1=\text { low }-7=\text { high } \\
\text { Risk Perception of pertussis in baby if not vaccinating }\end{array}$ & $10.21(7.10)$ & $9.68(6.23)$ & -0.53 & -1.67 & 0.62 \\
\hline $\begin{array}{l}\quad 1=\text { low }-49=\text { high } \\
\text { Risk Perception side effects vaccine }\end{array}$ & $7.59(6.42)$ & $5.29(5.77)$ & $-2.30^{*}$ & -3.35 & -1.25 \\
\hline $\begin{array}{l}\quad 1=\text { low }-49=\text { high } \\
\text { Risk Perception side effects vaccine for the child }\end{array}$ & $7.10(6.46)$ & $5.23(6.50)$ & $-1.87^{*}$ & -3.02 & -0.74 \\
\hline $\begin{array}{l}\quad 1=\text { low }-49=\text { high } \\
\text { Belief Safety }\end{array}$ & $3.94(1.06)$ & $4.35(1.23)$ & $0.41^{*}$ & 0.21 & 0.61 \\
\hline $\begin{array}{l}1=\text { unsafe }-7=\text { safe } \\
\text { Injunctive norm }\end{array}$ & $4.19(1.16)$ & $4.70(1.18)$ & $0.51^{*}$ & 0.31 & 0.72 \\
\hline $\begin{array}{l}1=\text { low }-7=\text { high } \\
\text { Descriptive norm }\end{array}$ & $3.84(1.15)$ & $4.30(1.24)$ & $0.46^{*}$ & 0.25 & 0.68 \\
\hline $\begin{array}{l}\qquad 1=\text { low }-7=\text { high } \\
\text { Anticipated regret of vaccinating }\end{array}$ & $5.02(1.43)$ & $4.75(1.54)$ & -0.27 & -0.54 & 0.00 \\
\hline $\begin{array}{l}1=\text { low }-7=\text { high } \\
\text { Decisional certainty }\end{array}$ & $3.62(1.32)$ & $3.96(1.57)$ & $0.34^{*}$ & 0.09 & 0.59 \\
\hline $\begin{array}{l}1=\text { certain }-7=\text { uncertain } \\
\text { Trust in NIP and healthcare professionals }\end{array}$ & $4.84(1.21)$ & $5.14(1.27)$ & $0.30^{*}$ & 0.08 & 0.52 \\
\hline $\begin{array}{l}\qquad 1=\text { low }-7=\text { high } \\
\text { Past Experience Pertussis }\end{array}$ & $0.23(0.42)$ & $0.27(0.44)$ & 0.04 & -0.04 & 0.12 \\
\hline $\begin{array}{l}\qquad 1=\text { no }-2=\text { yes } \\
\text { Past Experience Pertussis in a baby }\end{array}$ & $0.06(0.24)$ & $0.06(0.24)$ & 0.00 & -0.05 & 0.04 \\
\hline $\begin{array}{l}\qquad 1=\text { no }-2=\text { yes } \\
\text { Past Experience vaccine side effects baby }\end{array}$ & $0.29(0.46)$ & $0.25(0.44)$ & -0.04 & -0.12 & 0.04 \\
\hline $\begin{array}{l}\quad 1=\text { no }-2=\text { yes } \\
\text { Fear vaccination }\end{array}$ & $3.59(1.66)$ & $3.19(1.69)$ & $-0.40^{*}$ & -0.70 & -0.11 \\
\hline $\begin{array}{l}1=\text { low }-7=\text { high } \\
\text { Fear disease }\end{array}$ & $4.60(1.71)$ & $4.88(1.58)$ & 0.28 & 0.00 & 0.57 \\
\hline $\begin{array}{l}1=\text { low }-7=\text { high } \\
\text { Belief effectiveness MPV }\end{array}$ & $5.76(2.07)$ & $6.73(2.04)$ & $0.97^{*}$ & 0.60 & 1.32 \\
\hline $\begin{array}{l}1=\text { low }-10=\text { high } \\
\text { Belief effectiveness having Pertussis }\end{array}$ & $4.34(2.29)$ & $4.63(2.44)$ & 0.29 & -0.13 & 0.72 \\
\hline $\begin{array}{l}\quad 1=\text { low }-10=\text { high } \\
\text { Belief effectiveness breastfeeding }\end{array}$ & $5.89(2.59)$ & $5.79(2.46)$ & 0.10 & -0.54 & 0.34 \\
\hline $\begin{array}{l}\quad 1=\text { low }-10=\text { high } \\
\text { Belief effectiveness living healthily }\end{array}$ & $5.79(2.42)$ & $5.71(2.44)$ & 0,08 & -0.51 & 0.35 \\
\hline $1=$ low $-10=$ high & & & & & \\
\hline
\end{tabular}

Note. * Indicates a significance of the mean difference at the level of the $95 \%$ confidence interval. 
i.e. perceived severity of and perceived susceptibility to pertussis, should both be addressed individually in risk communication

Second, we recommend clinicians to encourage and facilitate pregnant women to actively make an informed decision on MPV. Being certain about their choice will provide pregnant women with a more robust attitude about vaccination, and will make them less vulnerable to misinformation. Because vaccination for pregnant women is a subject that involves emotions such as anticipated regret, fear for the vaccine and fear of the disease, taking their emotions and concerns seriously is important to facilitate an informed decision making process.

Our study shows that it is difficult to determine an MPV decision of women who are uncertain about MPV. When a pregnant women is in doubt about MPV, clinicians can provide help by actively checking whether potential misperceptions are present about safety of the vaccine, side-effects of the vaccine, and risk perceptions of the baby getting pertussis.

Furthermore, because pregnant women were found to have a lower attitude towards MPV and a lower vaccination intention than non-pregnant women, information provision may benefit from careful timing. Communication could address more cognitive factors when the decision is further in time ("cold", before pregnancy; e.g. addressing beliefs about safety and effectiveness and risk perception, whereas it could be more relevant to pay attention to possible concerns and related emotions that may arise when closer to the moment of decision ("hot", during pregnancy; e.g. addressing physical discomfort or feeling more protective about the unborn child on information given to pregnant women). This strategy could promote a robust attitude towards MPV before getting pregnant or early in pregnancy and ultimately, an informed decision.

All authors attest they meet the ICMJE criteria for authorship Funding

This work was supported by ZonMW, The Netherlands Organization for Health Research and Development [grant number 522004003].

\section{Declaration of Competing Interest}

The authors declare that they have no known competing financial interests or personal relationships that could have appeared to influence the work reported in this paper.

\section{Appendix A. Supplementary material}

Supplementary data to this article can be found online at https://doi.org/10.1016/j.vaccine.2020.07.047.

\section{References}

[1] McIntyre P, Wood N. Pertussis in early infancy: disease burden and preventive strategies. Curr Opin Infect Dis 2009;22:215-23. https://doi.org/10.1097/ oc0.0b013e32832b3540.

[2] van der Maas NAT, Mooi FR, de Greeff SC, Berbers GAM, Spaendonck MAEC, de Melker HE. Pertussis in the Netherlands, is the current vaccination strategy sufficient to reduce disease burden in young infants?. Vaccine 2013;31:4541-7. https://doi.org/10.1016/j.vaccine.2013.07.060.

[3] Health Council of the Netherlands. Vaccination against pertussis: aims and strategy. The Hague: Health Council of the Netherlands; 2015.

[4] Van Lier EA, Oomen P, Giesbers H, Van Vliet JA, Drijfhout IH, Zonnenberg-Hoff IF, et al. Vaccinatiegraad en jaarverslag Rijksvaccinatieprogramma Nederland 2018 2019. https://doi.org/10.21945/RIVM-2019-0015.

[5] Health Council. Advice vaccination against pandemic influenza A/H1N1 2009: target groups and prioritizing (publication 2009/16). Den Haag: Health Council of the Netherlands; 2009.

[6] van Lier A, Steens A, Ferreira JA, van der Maas NAT, de Melker HE. Acceptance of vaccination during pregnancy: Experience with 2009 influenza A (H1N1) in the Netherlands. Vaccine 2012;30:2892-9. https://doi.org/10.1016/ j.vaccine.2012.02.030
[7] Public Health England. Pertussis vaccination programme for pregnant women update: vaccine coverage in England, July to September 2017. Health Protection Report 2018;12:9.

[8] Kahn KE, Black CL, Ding H, Williams WW, Lu P-J, Fiebelkorn AP, et al. Influenza and Tdap Vaccination Coverage Among Pregnant Women - United States, April 2018. MMWR Morb Mortal Wkly Rep 2018;67:1055-9. https://doi.org/ 10.15585/mmwr.mm6738a3.

[9] Van Buynder PG, Van Buynder JL, Menton L, Thompson G, Sun J. Antigen specific vaccine hesitancy in pregnancy. Vaccine 2019;37:2814-20. https:/l doi.org/10.1016/i.vaccine.2019.04.021.

[10] Danchin MH, Costa-Pinto J, Attwell K, Willaby H, Wiley K, Hoq M, et al. Vaccine decision-making begins in pregnancy: Correlation between vaccine concerns, intentions and maternal vaccination with subsequent childhood vaccine uptake. Vaccine 2018;36:6473-9. https://doi.org/10.1016/ i.vaccine.2017.08.003.

[11] Wilson RJ, Paterson P, Jarrett C, Larson HJ. Understanding factors influencing vaccination acceptance during pregnancy globally: A literature review. Vaccine 2015;33:6420-9. https://doi.org/10.1016/j.vaccine.2015.08.046.

[12] Varan AK, Esteves-Jaramillo A, Richardson V, Esparza-Aguilar M, CervantesPowell P, Omer SB. Intention to accept Bordetella pertussis booster vaccine during pregnancy in Mexico City. Vaccine 2014;32:785-92. https://doi.org/ 10.1016/i.vaccine.2013.12.054.

[13] Hill L, Burrell B, Walls T. Factors influencing women's decisions about having the pertussis-containing vaccine during pregnancy. J Prim Health Care 2018;10:62. https://doi.org/10.1071/HC17040.

[14] Hayles EH, Cooper SC, Sinn J, Wood N, Leask J, Skinner SR. Pertussis vaccination coverage among Australian women prior to childbirth in the cocooning era: a two-hospital, cross-sectional survey, 2010 to 2013. Aust N Z J Obstet Gynaecol 2016;56:185-91. https://doi.org/10.1111/ajo.12429.

[15] Ko HS, Jo YS, Kim YH, Park Y-G, Wie JH, Cheon J, et al. Knowledge and Acceptability about Adult Pertussis Immunization in Korean Women of Childbearing Age. Yonsei Med J 2015;56:1071-8. https://doi.org/10.3349/ ymj.2015.56.4.1071.

[16] Winslade CG, Heffernan CM, Atchison CJ. Experiences and perspectives of mothers of the pertussis vaccination programme in London. Public Health 2017;146:10-4. https://doi.org/10.1016/j.puhe.2016.12.018.

[17] Campbell H, Van Hoek AJ, Bedford H, Craig L, Yeowell A-L, Green D, et al. Attitudes to immunisation in pregnancy among women in the UK targeted by such programmes. British J Midwifery 2015;23:566-73. https://doi.org/ 10.12968/bjom.2015.23.8.566.

[18] McQuaid F, Jones C, Stevens Z, Plumb J, Hughes R, Bedford H, et al. Factors influencing women's attitudes towards antenatal vaccines, group B Streptococcus and clinical trial participation in pregnancy: an online survey. BMJ Open 2016;6: https://doi.org/10.1136/bmjopen-2015-010790e010790.

[19] O'Shea A, Cleary B, McEntee E, Barrett T, O'Carroll A, Drew R, et al. To vaccinate or not to vaccinate? Women's perception of vaccination in pregnancy: a qualitative study. BJGP Open 2018. https://doi.org/10.3399/ bjgpopen18X101457.

[20] Bödeker B, Walter D, Reiter S, Wichmann O. Cross-sectional study on factors associated with influenza vaccine uptake and pertussis vaccination status among pregnant women in Germany. Vaccine 2014;32:4131-9. https://doi. org/10.1016/j.vaccine.2014.06.007.

[21] Laenen J, Roelants M, Devlieger R, Vandermeulen C. Influenza and pertussis vaccination coverage in pregnant women. Vaccine 2015;33:2125-31. https:/l doi.org/10.1016/j.vaccine.2015.03.020.

[22] Visser O, Kraan J, Akkermans R, Ruiter RAC, van der Velden K, Hautvast JLA, et al. Assessing determinants of the intention to accept a pertussis cocooning vaccination: A survey among Dutch parents. Vaccine 2016;34:4744-51. https://doi.org/10.1016/i.vaccine.2016.07.024.

[23] Janz NK, Becker MH. The Health Belief Model: A Decade Later. Health Educ Q 1984;11:1-47. https://doi.org/10.1177/109019818401100101.

[24] Ajzen I. The theory of planned behavior. Organizat Behavior Human Decision Processes 1991;50:179-211. https://doi.org/10.1016/0749-5978(91)90020-T.

[25] Pot M, Paulussen TG, Ruiter RA, Eekhout I, de Melker HE, Spoelstra ME, et al. Effectiveness of a Web-Based Tailored Intervention With Virtual Assistants Promoting the Acceptability of HPV Vaccination Among Mothers of Invited Girls: Randomized Controlled Trial. J Med Internet Res 2017;19:. https://doi. org/10.2196/imir.7449e312.

[26] Conner M, Norman P. Predicting health behaviour: research and practice with social cognition models. Maidenhead: Open Univ. Press; 2007.

[27] Chapman GB, Coups EJ. Emotions and preventive health behavior: worry, regret, and influenza vaccination. Health Psychol 2006;25:82-90. https://doi. org/10.1037/0278-6133.25.1.82.

[28] Tversky A, Kahneman D. Judgment under Uncertainty: Heuristics and Biases. Science 1974;185:1124-31. https://doi.org/10.1126/science.185.4157.1124.

[29] Slovic P, Finucane ML, Peters E, MacGregor DG. The affect heuristic. Eur J Oper Res 2007;177:1333-52. https://doi.org/10.1016/i.ejor.2005.04.006.

[30] Dubé E, Gagnon D, MacDonald N, Bocquier A, Peretti-Watel P, Verger P. Underlying factors impacting vaccine hesitancy in high income countries: a review of qualitative studies. Expert Rev Vacc 2018;17:989-1004. https://doi. org/10.1080/14760584.2018.1541406.

[31] O'Connor AM. Validation of a decisional conflict scale. Med Decis Making 1995;15:25-30. https://doi.org/10.1177/0272989X9501500105.

[32] Sparks P, Conner M, James R, Shepherd R, Povey R. Ambivalence about healthrelated behaviours: an exploration in the domain of food choice. $\mathrm{Br}$ J Health Psychol 2001;6:53-68. https://doi.org/10.1348/135910701169052. 
[33] Aiken LS, West SG, Reno RR. Multiple regression: testing and interpreting interactions. Nachdr. Newbury Park, Calif.: SAGE; 2003.

[34] Cohen J. Statistical power analysis for the behavioral sciences. 2nd ed. Hillsdale, N.J: L. Erlbaum Associates; 1988.

[35] Visser O, Hautvast JLA, van der Velden K, Hulscher MEJL. Intention to Accept Pertussis Vaccination for Cocooning: A Qualitative Study of the Determinants. PLoS ONE 2016;11:. https://doi.org/10.1371/journal.pone.0155861e0155861.

[36] Schwartz SH. Normative Influences on Altruism. Advances in Experimenta Social Psychology. Elsevier 1977;10:221-79. https://doi.org/10.1016/S00652601(08)60358-5.

[37] Rivis A, Sheeran P, Armitage CJ. Expanding the Affective and Normative Components of the Theory of Planned Behavior: A Meta-Analysis of
Anticipated Affect and Moral Norms. J Appl Soc Psychol 2009;39:2985-3019. https://doi.org/10.1111/j.1559-1816.2009.00558.x.

[38] Conner M, Povey R, Sparks P, James R, Shepherd R. Moderating role of attitudinal ambivalence within the theory of planned behaviour. $\mathrm{Br} \mathrm{J}$ Soc Psychol 2003;42:75-94. https://doi.org/10.1348/014466603763276135.

[39] van Harreveld F, Nohlen HU, Schneider IK. The ABC of Ambivalence. Advances in Experimental Social Psychology. Elsevier 2015;52:285-324. https://doi.org/ 10.1016/bs.aesp.2015.01.002.

[40] Armitage CJ, Conner M. Attitudinal Ambivalence: A Test of Three Key Hypotheses. Pers Soc Psychol Bull 2000;26:1421-32. https://doi.org/ $10.1177 / 0146167200263009$.

[41] Loewenstein G. Hot-cold empathy gaps and medical decision making. Health Psychol 2005;24:S49-56. https://doi.org/10.1037/0278-6133.24.4.S49. 